\title{
Prefix (hu) as a Cognate Morpheme in Old English and Avestan
}

\author{
Azad Hamawandy \\ Department of English, Basic Education, University of Sulaimani, Kurdistan Region, Iraq
}

Email address:

hamawandy.azad@yahoo.com

\section{To cite this article:}

Azad Hamawandy. Prefix (hu) as a Cognate Morpheme in Old English and Avestan. International Journal of Language and Linguistics. Vol. 3, No. 4, 2015, pp. 239-243. doi: 10.11648/j.ij11.20150304.17

\begin{abstract}
This study is confirms the historical lexical correlation between Old English Germanic group and Indo - Iranian group with the insights of lexical theories and analyze the origin of cognate morphemes particularly, this prefix (hu). The present study consists of four sections: The first section introduces the aims, the method of this study as a comparative analysis, etymology and prefix as a part of derivational morphemes. Section two investigates the origin of two groups of Indo European language family (IE) Viz. Germanic group and Indo - Iranian group, also comparing their daughter languages English language versus Kurdish language. Section three shows the origin of prefix (hu) as a similar morpheme between English and Kurdish languages, and giving examples as cognates between them and Avestan language. The last part is section four ; this section is about results and finally, the study points out some conclusions.
\end{abstract}

Keywords: Avestan, Old English, Cognate Morpheme

\section{Introduction}

Language is an enormous and very complex phenomenon, the aims of this study is confirming the historical and lexical correlation between particular languages. There is a genetic factor which is the standard way of demonstrating the real genetic relations of languages is by the means of comparative method.

Comparative historical linguistics is a branch of historical linguistics. A comparative analysis means the comparison of languages in order to find similarities between them. On the other hand, the comparison in order to pinpoint dissimilarities and similarities is known as contrastive linguistics.

In this way, it is by means of the comparative method that nineteenth century linguists, beginning with A. Schleicher in (1861), were able to initiate the reconstruction of the long lost parent language which linguists believe flourished about 6000 years ago, and they have been calling Indo - European.

This study will mention that for many languages, there are historical records which go back more than a thousand years. Also the realization of historical phonetic change of comparative cognates according to the rules of the comparative method. On the other hand, this morpheme $\{h u\}$ as cognate prefix has been recorded without semantic changes, my greatest triumph is that a comparative analysis of Old English and Avestan morphemes is more difficult than another comparative analysis of languages in the same group , for instance; Balto - Slavic group , Latin group, Indo Iranian group , or Germanic group , Celtic group............etc.

\section{What Is Etymology}

The method employed in this study owes historical linguists' procedures despite some superficial similarities between them. It is proved that etymologists will catch the thinnest straw to explain the origin of a hard word. According to Yule's glossary to define this term, etymology is the study of the origin and history of words (Yule, 2006:241), and Trask says : " The name etymology is given to the study of the origins and histories of individual words, and also to the history of a particular word". ( Trask, $2003: 345$ )

In this way, to originate prefix (hu) in Proto Indo European (PIE), " we shall therefore assume that the speakers of PIE occupied only such a modest area something like 6000 years ago, and they spread out from there over that eventually became the vast IE - speaking area of recorded history" ( Ibid. : 358) 


\section{Morphemes and Prefixes}

Morphemes are certainly part of the syntactic structure of language, morpheme is a the minimal unit of meaning, it is a word or a part of a word that has meaning and cannot be divided into smaller meaningful parts.

According to G. Yule's classification of different types of morphemes, there are two types of morphemes :

1. Free morphemes

2. Bound morphemes (Yule, 2006:66)

It is well known that affixes are bound morphemes, affixes are generally classified into three parts:

1. Prefixes

2. Infixes

3. Suffixes

It is usually believed that prefix (hu) goes back to some Proto Indo - European root, (hu) was one of numerous local Germanic words or Indo -Iranian words. Suffixes are more than prefixes in English language, N. C. Stageberg states that prefixes are those bound morphemes that can occur before a base as in insure, subway, preway, antifreeze, and imperfect. Prefixes in English are a small class of morphemes numbering about seventy five ( Stageberg 1995 : 9192 )..hence, the study will be focused on one prefix (hu) and investigated it.

\section{Indo - European Language Family}

First of all, to originate similar lexemes and investigate the origins and development of English / Germanic group and Avestan language/ Indo - Iranian group , their grandmother language (PIE), the origin of Indo - European language family is from mono language in the south of Russia. Then during Kurgan Age ( Bronze Age ) in the earlier half of the fourth millennium B. C., this group had moved to the Mountains / Zagros chains between Iraqi Kurdistan and Iranian Kurdistan.

It will be noted and be approved that the both languages are associated in the field of Indo - European language family which are common to India and Europe; applied to the great family or class of cognate languages spoken over the greater part of Europe and extending into Asia as far as northern India, and to the race or its divisions characterized by use of one or other of these languages. See Figure One:

\section{A Simplified Family Tree of Indoeuropean}

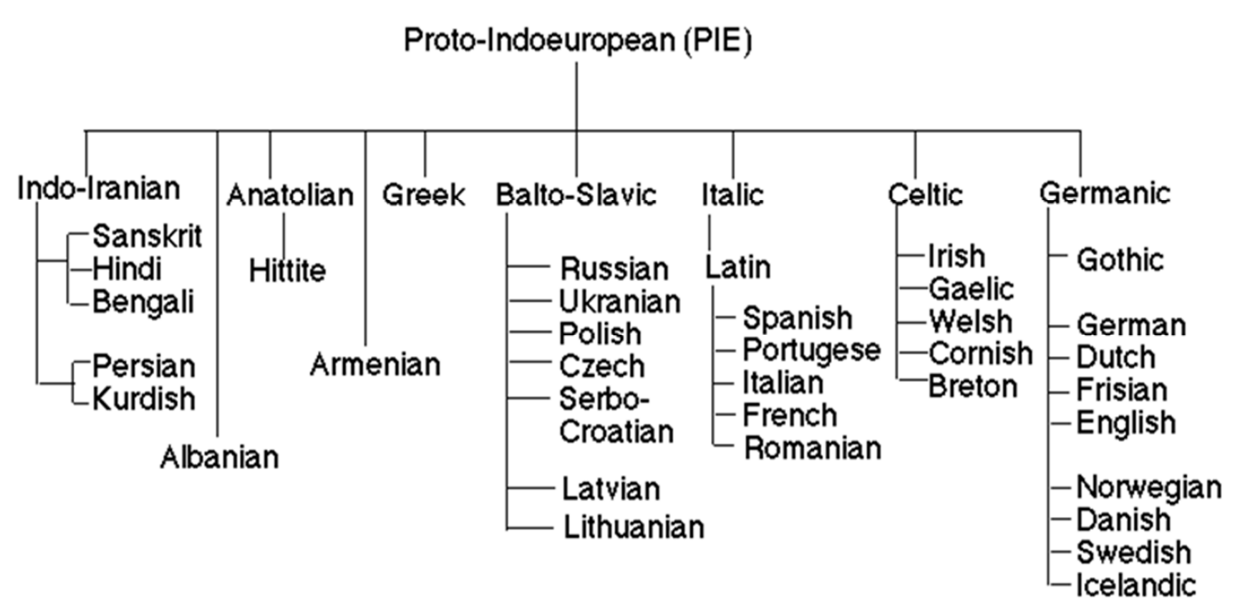

Figure 1. A Simplified Family Tree of Indo-European Languages.

\subsection{English and Germanic Group}

The history of the Germanic group begins with the appearance of what is known as Proto Germanic language. It is an entirely per- historical language; it was never recorded in written form. Proto - Germanic is the linguistic ancestor or the parent - language of the Germanic group. It is supported to have split from related Indo - European tongues between $1500-1000$ B. C.

Next period was in the seventh century A.D. because earliest texts of Germanic languages recorded in Old English (Anglo - Saxon), they are approximately dated $700-1050$. These languages of Germanic group and the whole language family have been reconstructed two centuries ago " In the $19^{\text {th }}$ century it was reconstructed by methods of comparative linguistics from written evidence in descendant languages " 1 .

\subsection{Avestan and Indo - Iranian Group}

Of course, this study will to break ground for the future scholars who will establish a definite corpus of (Centum ) and ( Satum ) roots in this area i.e. Particularly English and Avestan languages. Once again to originate the Kurdish language we must note that "Avestan is a language of the Avesta , the sacred book of the Zoroastrians" (Cable, 1983 : 25).

In this way, Indo - Iranian languages group is known in 
older literature as Aryan languages which constitute the longest and eastern most extant branch of the Indo European language family. It is proved that " there are about
(445) Indo - European languages and dialects, according to the estimate by Ethnologue, with over two- thirds (313) of them belonging to the Indo-Iranian branch alone" ${ }^{2}$.

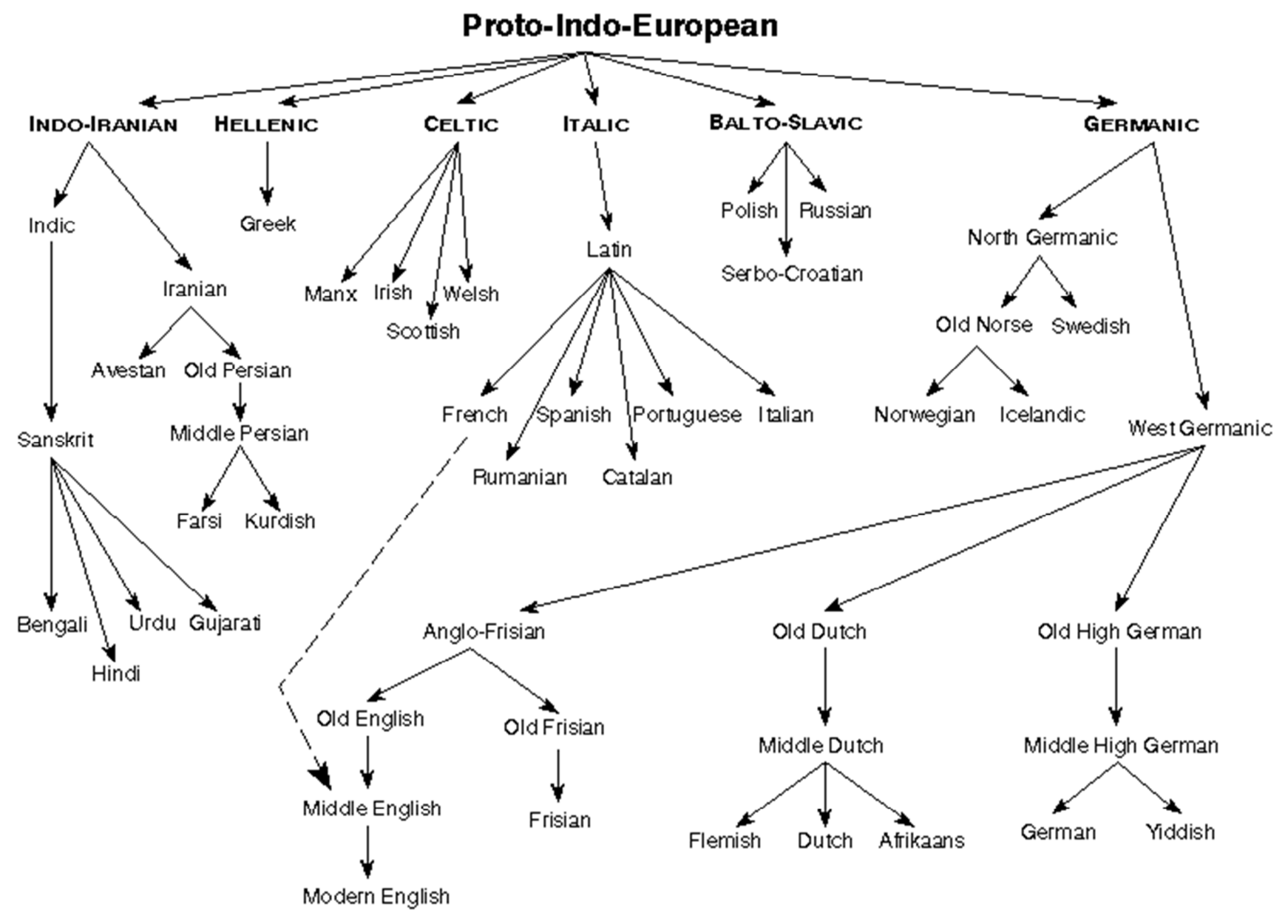

Figure 2. Proto - Indo - European Groups.

It is well known that Gothic language is a part of Germanic group (East Germanic), now it is extinct, and no granddaughter language. See Figure Two / Proto - Indo European Groups. In the middle of the first millennium Gothic was extinct, also focus on Avestan in the first millennium B.C. , in the same time there were inscriptions in Old Persian at Behstun mountains near Kermanshah/ Iran. Also Sanskrit (Vedic texts) in the second millennium B.C. in the eastern part of PIE (Satum). On the other hand, there were Greek and Latin languages in the western part of PIE (Centum) i.e. centum in Latin and Satum in Avestan are lexical items mean one hundred, cent and sat in modern languages.

According to linguistic ancestors or parent languages of PIE, Avestan language has descended the present Modern Kurdish, and the scientific councils of University of Kirkuk and University of Sulaimani have supported my academic researches about Avestan and modern Kurdish (Hamawandy, 2012 : 29) cf. (Hamawandy, 2014: 356). Avesta is the sacred book of Zoroastrian religion, the oldest texts/ poems called Gathas i.e. Verses, " the Gathas are dated approximately 600
B.C. and are as archaic in language as those of the Rigveda ; because numerous problems in transmission, the Gathas are very difficult to interpret " (Lehmann, 1973: 23), kings of Mede Empire had arrived Assyrian Empire in 612 B.C. in Nineveh/ Mosul / Northern Iraq. In other words Kurdish people had constructed their calendar since that ancient event in the seventh century before Jesus's birthday; their history in the current time is 2715 .

First of all, according to chronology, before 300 B.C. was the old period for Sanskrit, Avestan, and Old Persian. In 331 B.C. Alexander The Great occupied Medya Empire and eastern countries, after translating to Latin Avesta had been burnt by Alexander. All Iranian texts are handed down to us in two dialects, the Avestan and Old Persian, a scared language Avestan was the language of Medes i.e. during Medea/ Medya Empire

Then Middle Indic (Paili), Middle Kurdish (Phaili), and Middle Persian (Pahlavi) from 300 B.C. to 900 A.D. Zoaroster's followers collected verses which entitled Zend not Avesta. Unfortunately, Sassanid kings insisted and authorized to write Zend in Pahlavi not Phaili (Phaili is one 
of four Kurdish dialects nowadays in Kermanshah/ Iranian Kurdistan and Xanaqin/ Iraqi Kurdistan . Some Kurdish texts had preserved, one more time these texts and Kurdish people became victims of Islamic conquers who arrived Kurdistan in 639-640,they were savage conquers like ISIS groups, destroyed Kurdish social and cultural entity, vanished Kurdish heritage, in the next decades Zoroaster's followers from Kurdistan and Iran " fled to India at the time of the Mohammedan conquest of their country in the eighth century" ( Pyles, 1971: 98).

Finally, Modern Indic (Hindustani), Modern Avestan (Modern Kurdish ) and Modern Persian (Farsi) started since 900 A.D. in Kurdistan exactly in 935 or Baba Tahiri Hamadani's birthday who wrote the first poem in Modern Kurdish mixed with Phaili, it is well known that " Modern ethnographers believe that the Kurds are descendants of the Medes who migrated from the Eurasian steppes in the second millennium B.C." ( Nyrop, 1980: 11) , therefore , this research will be rejected Thomas Pyles's suggestion who says " there are no modern descendants of Avestan, which is by some believed to be the language of the Medes" ( Pyles, 1971: 97).

\section{Prefix \{ hu $\}$ as a Cognate Morpheme}

Language is a mean of communication. Languages can be classified according to different principles, for instance; the historical classification, or genealogical classification. All live languages in accordance with their origin form a common linguistic ancestor, genetically; English belongs to the Germanic group, Kurdish belongs to Indo - Iranian group To study a cognate prefix $\{\mathrm{hu}\}$ and investigate its origin " the study of language is one of the oldest branches of systematic inquiry, tracing back to classical India and Greece, with a race and fruitful history of achievement. From different point of view, it is quite young " (Chomsky, 2000: 3).

Prefix $\{h u\}$ as a cognate morpheme is the hypothesis of this study, in the remote past, particularly, in Latin " Man is not a cognate of Latin (homo) through an etymon beginning with /ghm-/" (Leberman, 2008: xlii) Gothic word ghman means both slave and servant, in other words it is a part of Germanic group (East Germanic) and the word semantically means man or human being of either sex-male " (ibid.) "

\subsection{Prefix $\{h u\}$ in English Language}

Old English (450-1100)

Middle English (1100-1500)

Modern English (1500-2015)

It was noticed very early by European linguists that languages can differ very substantially in the nature of their morphological systems in the early nineteenth century. English language is an isolating language " In an isolating language, there is no morphology at all, and every word consists of a single morpheme. " ( Trask, 2003 : 125).

" Most notably in the Germanic group , particularly, English is an isolating language according to the types of morphemes" ${ }^{3}$.
Only one word is the specific target of this study Viz./ human /, to clarify this word which includes two morphemes $\mathrm{hu}+$ man. To originate this word etymologically $\{\mathrm{hu}\}$ or \{hue $\}$ in Anglo - Saxon was $\{$ hiw , and in Middle English was \{hewe\} meant show, good, appearance, colorful. On the other hand, these two morphemes together \{human\} in Latin means a good creature of earth (Skeat, 1993 : 210-211) like Avestan or Old Germanic.

\subsection{Prefix $\{h u\}$ in Avestan Language}

Actually, a sacred language (Avestan) sometimes incorrectly called

Zend, Avesta was collected in the middle period of Iranian languages

Chronologically, the new manuscripts called Zend . These morphemes were Prophet Zoroaster's advises or the principles of Zoroater's philosophy in Zoroastrianism:

1. $\mathrm{hu}+\mathrm{xta}$

2. hu + rshta

3. hu + mata

To shed light on the first advise huxsta , $\{$ hu $\}$ meant good and xta or ksta in Phaili or (qsa) in Modern Kurdish means speech/ words, the whole morphemes meant good speech, good words.

The second advise is hurshta, $\{$ hu $\}$ meant good and rshta or (rawsht) in Modern Kurdish means deed/ moral, the whole morphemes or two cognates together meant good deeds.

The last advise is humata, $\{\mathrm{hu}\}$ meant good and mata meant thinking/ thought, the combined morphemes meant good thought/ good idea, the last morpheme is not same in Modern Kurdish, but changed to matal means riddle or thinking, the second hypothesis is meshk (brain/mental) ${ }^{4}$.

\subsection{Prefix $\{h u\}$ in Modern Kurdish Language}

Old Kurdish (700 - 300 B.C.) Avestan/

Middle Kurdish (300 B.C. - 900 A.D) Phaili/

Kurdi/Modern Kurdish ( 900 A.D - 2015 )

Kurdish belongs to Avestan, in numbers of native speakers, modern Kurdish with 40 - 50 million people in Turkey, Iran, Iraq , Syria, Lebanon and Russia. Modern Kurdish or Kurdish language belongs to Indo - Iranian group, also it is a part of Indo - Iranian group and

Persian, Pashto , Kurdish......etc. are forming the Iranian branch ""

(Bynon, $1977: 23$ )

Actually, Modern Kurdish is descended from Avestan, only one word has continued till current time Viz./ huner / which includes two morphemes : hu (good $)+\operatorname{ner}(\operatorname{man} /$ male $)=\mathrm{a}$ good man

This word / huner / changed semantically, it means art or fantastic. In the remote past / hunera / also meant a good man / good male/ good creature (Sadiq 2011 : pp. 130-131).

\section{Results and Conclusions}

This study seeks to demonstrate the origin of English and 
Avestan morphemes, particularly to study prefix $\{h u\}$. Also it seeks investigate and discuss the mysteries and problems that are perceived during the period of preparing and accomplishing it, particularly current analysis and its results about the granddaughter language of Avestan i.e. Modern Kurdish. The following etymologies aim at making the conclusions reached in the present study easily available to those who are more interested in the results of the investigation than in going over conflicting hypothesis.

Eventually, this paper tackled and reached the following points :

1- This prefix $\{h u\}$ is descended from Proto Indo European morphemes, as etymology of interest only to scholars and researchers who wish to study the history of languages.

2- $\{\mathrm{hu}\}$ is an old morpheme because there is only one type of this prefix has been continuing in Modern English and Modern Kurdish since 2-3 millennia ago.

3- Modern Kurdish is the granddaughter language of Avestan language.

It is NOT a part of Middle Persian as mentioned in Figure Two/ Proto

Indo - European Groups by Jack Lynch or like Thomas Pyle's suggestions.

4- Most notably in the Old statement "the law of the Medes and Persians ", this ancient verse meant Medes were ancestors of Kurds NOT Persians, and Kurdish is descended from Avestan not Old Persian or Middle Persian.

5- There are hundreds of cognates in Avesta and Modern Kurdish Viz. satum $=$ sat(hundred) $/$ azem $=\mathrm{az}(\mathrm{I}) /$ bumi=buma(earth) $/$ vasha $=$ wsha (word) $/$ aspa $=$ asp(horse) $/$ $\operatorname{varaza}=$ baraz(pig) $/$ vahasht $=$ bahasht or pirdoza $=$ piroza (paradise)...... etc.

\section{Notes}

1- Germanic languages are available at http://www. ku. It/ hmf/ files/2012/09/Bernotience_ Germanic_languages.pdf retrieved on $5^{\text {th }}$ of March, 2015.

2- Indo- European languages are available at http://www. en.wikipedia.org/wiki/Indo-european_languages retrieved on (Newroz) $21^{\text {st }}$ of March, 2015.

3- isolating language is available at http://www.britanica.com/EB checked/ topic/296308/isolating language. retrieved on $22^{\text {nd }}$ of April, 2015.
4- Avestan language is available at http://www. avesta.org/advict/Advict.htm retrieved on 25/5/ 2015.

\section{References}

[1] Baugh, A. C. \& Thomas Cable (1983) A History of the English Language. ( London : Routledge \& Kegan Pall ), $3^{\text {rd }}$ edition.

[2] Bynon , Th. (1977) Historical Linguistics . (London : New York : Melbourne : Cambridge University Press).

[3] Chomsky, Noam (2000) New Horizons in the Study of Language and Mind. Cambridge University Press, $1^{\text {st }}$ edition

[4] Leberman, A. (2008) An Analytic Dictionary of English Etymology. University of Minnesota Press. London

[5] Lehmann, W. P. (1973) Historical Linguistics - An Introduction - ( New York : Holt, Rinehart \& Winston Inc. ), $2^{\text {nd }}$ edition.

[6] Nyrop, R. F. (1980) TURKEY - A country study -ess), $3^{\text {rd }}$ edition.

[7] Pyles, Th. (1971) The Origins \& Development of the English Language. ( New York : San Francisco : Harcourt B. J. Inc.), $2^{\text {nd }}$ edition.

[8] Qani'a, W. (2013) The History of Zoroastrianism Jamal Erfan Cultural Association Press, Sulaimani/ Kurdistan region / Iraq. $1^{\text {st }}$ edition.

[9] Sadiq, F. O. (2011) Etymology. $1^{\text {st }}$ edition. Shivan Press, Sulaimani, KRG - Iraq

[10] Skeat, W. (1993) The Concise Dictionary of English Etymology. Wordsworth Reference Editions Ltd. UK.

[11] Stageberg, N. C. (1995). An Introductory English Grammar. $4^{\text {th }}$ edition. Holt, Rinehart and Winston Inc. USA.

[12] Trask, R. L. (2003) Historical Linguistics. Arnold/A member of the Hodder Headline Group, London.

[13] Yule, G. (2006) The Study of Language . 13- $3^{\text {rd }}$ edition, Cambridge University Press.

[14] Hamawandy, Dr. Azad (Kirkuk University Journal)

[15] Volume (7), Number (3), Year 2012, pp. (28-46)

[16] Hamawandy, Dr. Azad ( Sulaimani University Journal / Part B)

[17] No. (44), February (2014), pp. (353-364) 